\title{
50. X-RAY DIFFRACTION AND CHEMICAL STUDY OF SECONDARY MINERALS FROM DEEP SEA DRILLING PROJECT LEG 51 HOLES 417A AND 417D
}

\author{
K. F. Scheidegger and Debra S. Stakes, School of Oceanography, Oregon State University, Corvallis, Oregon
}

\begin{abstract}
Secondary minerals found in fracture fillings and in fragments of altered basalt from Holes 417A and 417D were studied by both X-ray diffraction and chemical techniques. Minerals found in fracture fillings from Hole 417A are dominated by montmorillonite, "protoceladonite," analcite, and lesser saponite; celadonite and ferrosaponite are the characteristic secondary minerals in Hole 417D fracture fillings. Assuming that minerals found in such fracture fillings reflect the composition of the secondary fluids that produced them, it is apparent that those from Hole 417A were dominantly Al-rich, while those from Hole 417D were more enriched in $\mathrm{Fe}, \mathrm{Mg}$, and $\mathrm{K}$. X-ray diffraction study of bulk samples support such fundamental differences in secondary mineralogy. In addition, the X-ray data on bulk samples suggest that primary plagioclase is the feldspar in Hole 417D rocks, and secondary potassium feldspar is the feldspar in Hole 417A altered rocks.

Using available published data on secondary mineral- found in other altered oceanic crust, it is possible to interpret the ditferences in secondary mineralogy that exist between the two sites. Secondary minerals present in Hole 417D rocks are believed to have formed under hydrothermally influenced, low temperature, nonoxidative diagenesis; whereas, those present in Hole 417A were produced under similarly low temperatures, but much more highly oxidizing conditions. The fundamental differences in secondary mineralogy between the two sites can be best explained by the accompanying remobilization of elements that involved plagioclase alteration in Hole 417A rocks. A comparison of the composition of Hole 417A and 417D secondary minerals with those found in younger crust suggests that the age of crust, influenced by the changing conditions of alteration, control the chemistry of secondary minerals found in available pore spaces in altered rocks. Minerals found in young crust ( $<15$ m.y.B.P.) are highly Mg-rich; minerals found in crust of intermediate age ( $\sim 15-50$ m.y.B.P.) are dominantly enriched in $\mathrm{Fe}$ and $\mathrm{Mg}$; and those found in older crust have higher contents of $\mathrm{Al}$ and $\mathrm{K}$.
\end{abstract}

\section{INTRODUCTION}

Petrologists, who attempt to evaluate both local and regional variations in the composition of oceanic basement rocks, require knowledge of the extent and nature of chemical alteration to their samples. The secondary changes can be induced by prolonged contact of basement rocks with cold sea water or hydrothermal fluids, or by metamorphism. Many of the general chemical changes brought about by exposure to cold sea water have been described (e.g., Hart, 1970; Hart and Nalwalk, 1970; Frey et al., 1974). However, as Scott and Hajash (1976) have demonstrated, chemical changes brought about by even this type of alteration may be quite variable. Many of the observed different patterns of alteration may be more readily understood from the results of recent laboratory studies (Seyfried and Bischoff, 1977; Seyfried and Mottl, 1977). The chemistry of circulating fluids, the temperature of solutions, and/or water:rock ratios can all have a dramatic effect on the nature and degree of alteration. It follows, too, that particular types of alteration may be indicated by particular secondary mineral assemblages or the compositions of particular secondary minerals. Thus, it becomes obvious that if petrologists are to understand the nature and magnitude of secondary chemical changes that modify original magma chemistries or the conditions under which basement rocks are altered, they must be able to interpret properly such secondary mineral assemblages.

Studies of altered basement rocks recovered by deep ocean drilling during the DSDP and IPOD programs, and by conventional dredging from surface vessels, have not kept pace generally with petrological studies of fresh sea floor pillow basalts recovered from the same areas. We know surprisingly little about the chemistry and mineralogy of secondary mineral phases in altered basement rocks, both regionally and with depth in the section. Recent studies of altered rocks from the Nazca plate in the southeast Pacific (Bass, 1976, Seyfried et al, 1973; Scott and Swanson, 1976; Scheidegger and Stakes, 1977) and the Atlantic (e.g., Matthews, 1971; Banks, 1972; Melson and Thompson, 
1973; Andrews, 1977; Baragar et al., 1977; Scarfe and Smith, 1977) have begun to fill in this void. However, available data on the chemistry and mineralogy of secondary minerals are still meager and virtually nothing is known about the alteration products associated with very old $(100+$ m.y.B.P.) oceanic crust. In addition, we have little information on how the compositions of secondary phases are related to the solutions that produced them. Unanswerable at this time is the question: "Are the alteration products found in the oldest oceanic crust different from or the same as those associated with younger oceanic crust?",

In this report, we present chemical and mineral data on alteration products found in basement rocks recovered from Holes 417A and 417D, which were drilled during DSDP Legs 51 and 52 . Our primary objectives are to:

1) Determine the nature of the secondary mineral assemblages associated with each site so that both differences in secondary mineralogy between and within the crustal sections can be evaluated.

2) Evaluate the chemistry and mineralogy of secondary minerals found in cavities and veins from Holes 417A and 417D.

3) Compare the chemical and mineral characteristics of phyllosilicates found in altered rocks recovered from Holes 417A and 417D with other published data on similar products recovered from younger, but altered crustal rocks from other parts of the ocean basins.

\section{SAMPLING AND METHODS OF ANALYSIS}

During DSDP Legs 51 and 52, Holes 417A and 417D were drilled successfully to depths of 206 and 195 meters, respectively, in 108-m.y.-old oceanic basement (Figure 1).
Shipboard scientists sampled available rock cores from each hole at approximately 10 meter increments for the purposes of this investigation. Megascopically different lithologies were sampled, and attempts were made to obtain samples which had vein and cavity fillings. A total of 49 samples believed to be representative of altered rocks found at each site were subsequently received. After examination of all samples, thin sections of 23 samples were prepared which represent the apparent existing diversity of altered basement rocks. From this subpopulation, seven mineral separates, scraped from fracture fillings, were obtained for mineral and chemical analyses. In addition, 10 other samples were subjected to bulk analysis by X-ray diffraction. The samples selected for study from each site are shown in Figure 2.

Mineral data described in this report were obtained by $\mathrm{X}$-ray diffraction using $\mathrm{Ni}$-filtered, monochromatic $\mathrm{Cu} \mathrm{K} \alpha$ radiation. For the mineral separates, small $(\sim 50 \mathrm{mg})$ splits of samples were ground and dispersed in distilled water; for the bulk mineral work, 5 -gram chunks of altered rock were ground in distilled water for 1 hour and the $<2 \mu \mathrm{m}$ fraction was separated by repeated settling and decantation. Each type of sample was treated with buffered glacial acetic acid $(p \mathrm{H}=5)$ to remove calcite. Subsequent to calcite removal, each sample was washed several times in deionized, distilled water. For each sample, one random untreated slide, one magnesium-saturated, glycerol-solvated slide, and one magnesium-saturated, glycolated slide were prepared. The random slides were scanned from 5 to $70^{\circ} 2 \theta$ using a scan speed of $0.5^{\circ} 2 \theta / \mathrm{min}$ and a 10 -second time constant, and also between 59.0 and $62.5^{\circ} 2 \theta$ at 0.25 $2 \theta / \mathrm{min}$ to study 060 reflections. Oriented slides were scanned between 3 and $30^{\circ} 2 \theta$ using a scan speed of $0.5^{\circ} 2 \theta / \mathrm{min}$

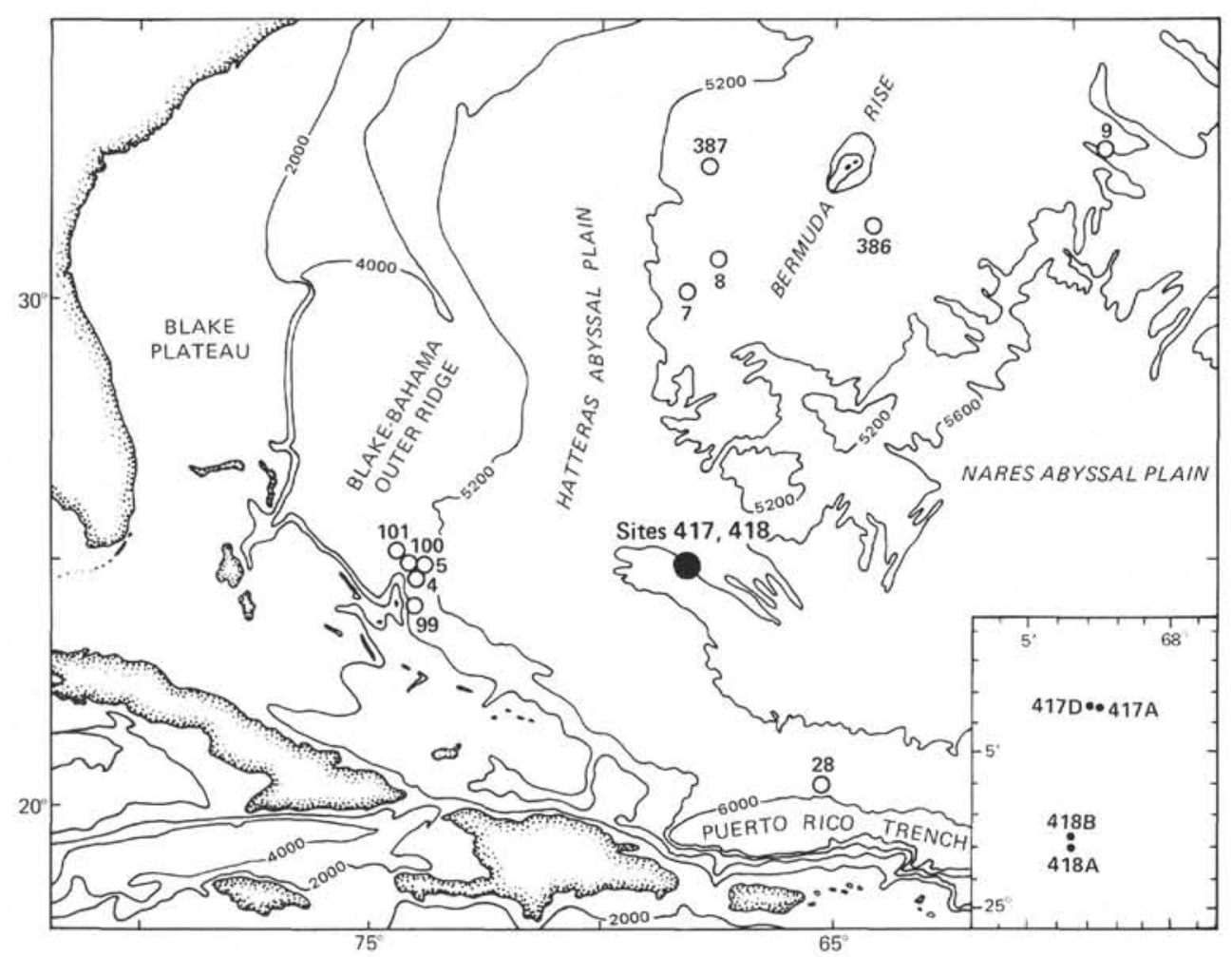

Figure 1. Illustration showing the location of Site 417 , where Holes $417 \mathrm{~A}$ and $417 \mathrm{D}$ were drilled during DSDP Legs 51 and 52. 

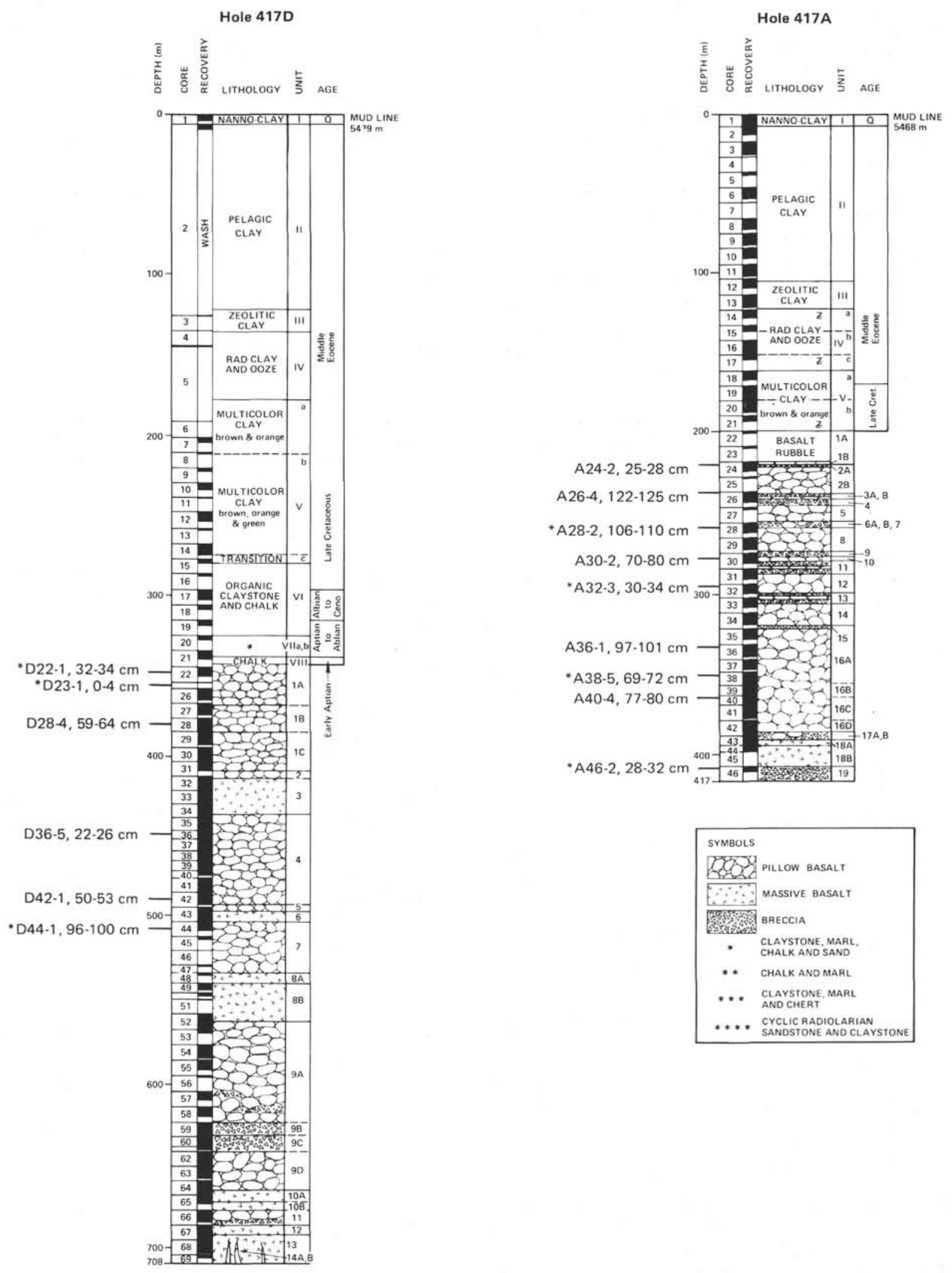

Figure 2. Locations of samples selected for chemical and mineral studies are shown relative to recognized lithologic units. Samples from which minerals were separated from fractures are shown by (*). 
and a 10-s time constant. Chemical data on mineral separates were obtained by atomic absorption spectrophotometric and colorimetric techniques (Scheidegger and Stakes, 1977) on approximate 50-mg samples.

\section{MINERALS SEPARATED FROM FRACTURE FILLINGS}

Minerals present in veins, vesicles, and fractures can provide potentially useful information on the chemistry of fluids which have permeated through the rocks with time (Scheidegger and Stakes, 1977). In addition, since significant amounts of secondary phases can be found in such localized areas in altered crustal rocks, detailed mineral and chemical analyses can be readily performed, thereby providing useful information on the compositional characteristics of mineral precipitates. The potential problems of mineral contamination by primary minerals from adjacent rock or the problem of intimate mixtures of secondary phases are always present. However, unlike chemical studies performed by electron microprobe, bulk wet-chemical analyses can be easily combined with X-ray diffraction study of the same mineral separates, and possible effects of such "contamination" can be better evaluated.

Representative diffractograms of the mineral separates obtained from Mg-saturated, oriented, glycerol-solvated and glycolated slides are shown in Figure 3. Study of these patterns reveals that most diffractograms are dominated by the expanded 16.8 or $17.8 \AA 001$ peak of a glycolated or

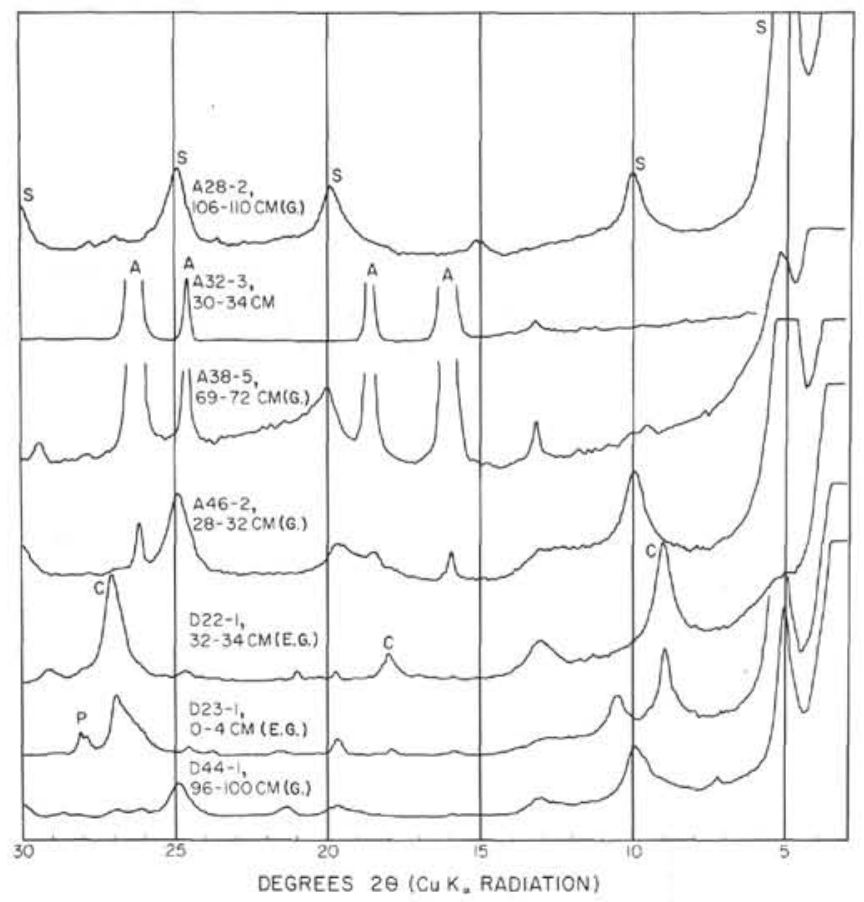

Figure 3. X-ray diffraction patterns of minerals found in fracture fillings from altered basaltic rocks recovered from DSDP Holes $417 A$ and $417 D$. $S=$ smectite, $C=$ celadonite, $A=$ analcite, and $P=$ plagioclase. Note the presence of crystalline celadonite in the two uppermost samples from Hole 417D. Diffractograms are of either glycolated (E.G.), glycerol-solvated (G), or untreated, oriented mounts. glycerol-solvated smectite; or the $9.8 \AA$ peak of a micaceous mineral; or the $3.42,4.83$, and $5.58 \AA$ peaks of a zeolite (analcite). Other minerals present include a trace amount of a plagioclase feldspar (peak near $28^{\circ} 2 \theta$; Sample 417D-23-1, 0-4 cm) and a possible smectite-micaceous mixed-layer mineral (peaks near 7 and $13^{\circ} 2 \theta$ ) in samples from Hole 417D. From the data presented in Figure 3, it is apparent that minerals found in veins and cavities in Hole 417A rocks are smectites and analcite; whereas, comparable materials in Hole 417D rocks are smectite, micaceous minerals, or smectite-micaceous mixed-layer minerals.

Chemical data on the analcite from Sample 417A-32-3, 30-34 $\mathrm{cm}$ are presented in Table 1 . The data indicate that the analcite is pure, although chemically it contains slightly more $\mathrm{SiO}_{2}$ and slightly less $\mathrm{Al}_{2} \mathrm{O}_{3}$ and $\mathrm{Na}_{2} \mathrm{O}$ than other reported analyses of analcite (see Deer et al., 1965). In addition, the absence of some expected hkl reflections between 27 and $30^{\circ} 2 \theta$ (see Figure 3 ) indicates that the mineral is not entirely cubic (Deer et al., 1965), an observation confirmed by the very weak birefringence of the mineral in thin section. Data presented in Figure 3 suggest that analcite is also present in Samples 417A-38-5, 69-72 cm and 417A$46-2,28-32 \mathrm{~cm}$.

Combined X-ray diffraction analyses of $2 \theta$ interval between 59.0 and $62.5^{\circ}$ (Figure 4 ) and bulk chemical study of the mineral separates (Table 1) have made possible a more complete characterization of the phyllosilicates present in samples from Holes 417A and 417D. Considering first the data for Sample 417 A-28-2, 106-110 cm, we find that the diffractogram from an oriented, glycerol-solvated slide (Figure 3 ) indicates that this mineral is a pure smectite with no aluminous zeolites or feldspars as contaminants. Inspection of the 060 reflections for this sample indicates that both a trioctahedral smectite (spacing of $1.532 \AA$ ) and a dioctahedral phyllosilicate (broad peak between 1.496 and $1.507 \AA$ ) are present. Such 060 spacings compare with the 1.520 and $1.535 \AA$ spacings of nontronite and saponite reported by Scheidegger and Stakes (1977) for similar types of fracture fillings found in altered rocks from the Peru-Chile Trench. The absence of a $1.520 \AA$ spacing (Figure 4) and the comparatively low Fe content of the clay (Table 1) argue against the presence of nontronite, the dioctahedral smectite. Instead, we suggest that it is reasonable that the broad "doublet"' of 1.496 and $1.507 \AA$ peaks correspond, respec-

TABLE 1

Chemical Analyses of Secondary Minerals Found in Fractures of Altered Basalts Recovered From DSDP Holes 417A and 417D (total iron has been calculated as $\mathrm{Fe}_{2} \mathrm{O}_{3}$; all values are weight per cent)

\begin{tabular}{|c|c|c|c|c|c|c|c|}
\hline in & $\begin{array}{l}\text { A28-2, } \\
106-110\end{array}$ & $\begin{array}{c}\text { A32-3, } \\
30-34\end{array}$ & $\begin{array}{l}\text { A38-5, } \\
69-72\end{array}$ & $\begin{array}{c}\text { A } 46-2, \\
28-32\end{array}$ & $\begin{array}{l}\text { D22-1, } \\
32-34\end{array}$ & $\begin{array}{c}\text { D23-1, } \\
0-4\end{array}$ & $\begin{array}{l}\text { D44-1, } \\
96-100\end{array}$ \\
\hline $\mathrm{SiO}_{2}$ & 51.87 & 57.20 & 56.60 & 48.30 & 54.76 & 48.46 & 46.25 \\
\hline $\mathrm{Al}_{2} \mathrm{O}_{3}$ & 15.09 & 23.01 & 20.74 & 13.02 & 9.32 & 6.27 & 5.48 \\
\hline $\mathrm{Fe}_{2} \mathrm{O}_{3} \mathrm{*}$ & 8.27 & 0.10 & 2.82 & 10.26 & 13.34 & 20.31 & 22.28 \\
\hline $\mathrm{MgO}$ & 9.57 & 0.04 & 1.13 & 11.89 & 5.33 & 7.62 & 13.21 \\
\hline $\mathrm{CaO}$ & 1.77 & 0.12 & 0.21 & 1.66 & 0.71 & 2.39 & 0.75 \\
\hline $\mathrm{Na}_{2} \mathrm{O}$ & 1.08 & 11.44 & 9.42 & 1.88 & 0.15 & 1.05 & 1.41 \\
\hline $\mathrm{K}_{2} \mathrm{O}$ & 1.99 & 0.15 & 0.50 & 1.60 & 6.42 & 4.51 & 2.03 \\
\hline $\mathrm{TiO}_{2}$ & 0.59 & 0.03 & 0.05 & 0.24 & 0.26 & 0.38 & 0.14 \\
\hline Total & 90.23 & 92.09 & 91.47 & 88.85 & 90.29 & 90.99 & 91.55 \\
\hline
\end{tabular}




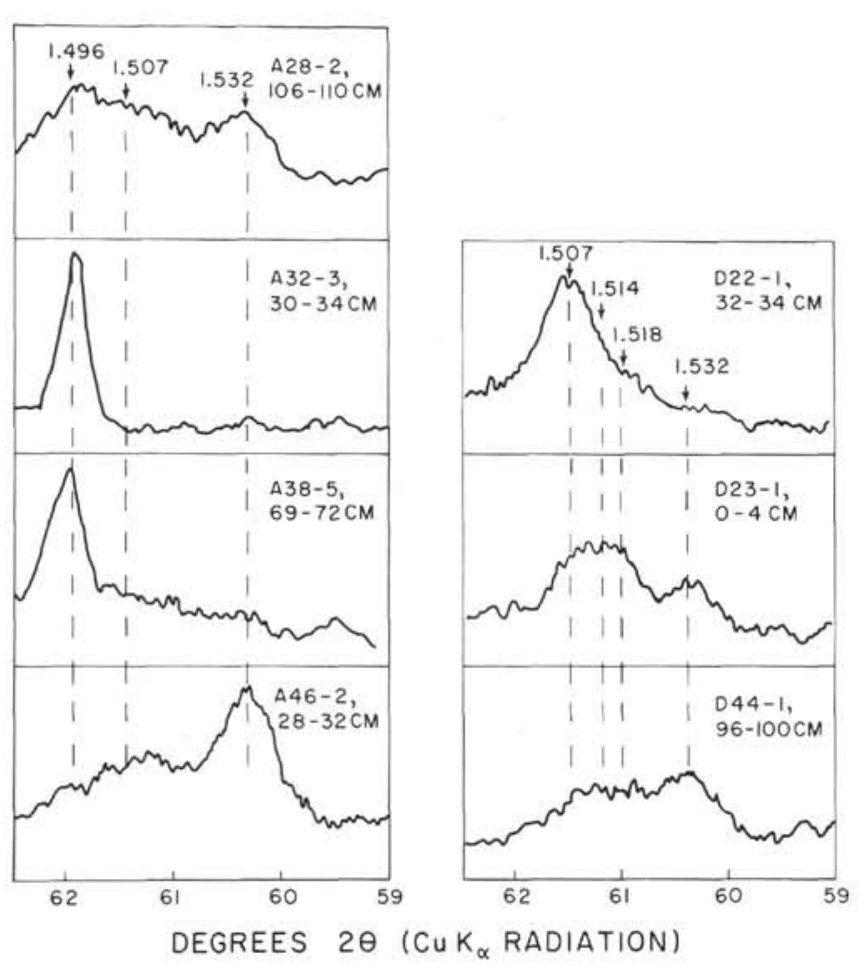

Figure 4. X-ray diffraction patterns of $2 \theta$ interval between 59.0 and $62.5^{\circ}$ where 060 reflections of phyllosilicates occur. The scans are of random mounts of the same samples illustrated in Figure 3. Numbers above arrows correspond to spacings in $\AA$. For Samples 417A-32-3, $30-34 \mathrm{~cm}$ and $417 A-38-5,69-72 \mathrm{~cm}$, the strong "060" reflection is associated with the (842) peak of analcite. Note the presence of a $1.496 \AA$ peak in analcite-free samples from Hole 417A, a peak believed to be associated with montmorillonite.

tively, to the dioctahedral smectite, montmorillonite, and a $\mathrm{K}$-rich dioctahedral mica-like mineral, "proto-celadonite", (see discussion by Donnelly, this volume). The high $\mathrm{K}_{2} \mathrm{O}$ content of Sample 417A-28-2, 106-110 cm and the 060 reflection for celadonite near $1.503 \AA$ (Zvyagin, 1957) to $1.510 \AA$ (Seyfried et al., 1976) argue for the existence of such a potassium-rich, micaceous phyllosilicate. In addition, there is a suggestion that the 002 smectite reflection is skewed somewhat toward lower $2 \theta$ values (see Figure 3 ), a result that would be consistent with a small amount of weakly crystalline celadonite. Further support for the presence of montmorillonite comes from the strong relative 005 reflection, an apparent characteristic of montmorillonites (MacEwan, 1961; Figure 3), and the aluminous nature of the clay (see Table 1). On the basis of the available data, we suggest that the phyllosilicates present in Sample 417A-28$2,106-110 \mathrm{~cm}$ are saponite, montmorillonite, and "protoceladonite.",

Similar arguments can be given for the mineralogy of clay minerals found in other Hole 417A mineral separates. For Sample 417A-38-5, 69-72 cm, it is obvious that the abundance of analcite (Figure 3 ) controls the chemistry of this cavity filling (Table 1). Evaluating the nature of the octahedral structure of the associated phyllosilicates is made difficult by the presence of the prominent " 060 " reflection of the (842) analcite peak at $1.496 \AA$ (see Figure 4). For Sample 417A-38-5, 69-72 cm, elemental abundances not associated with analcite (e.g., high $\mathrm{Fe}_{2} \mathrm{O}_{3} / \mathrm{MgO}$ ratio; Table 1) indicate that dioctahedral phyllosilicates are likely present, a suggestion supported by the near-absence of a reflection near $1.532 \AA$ and a stronger reflection near $1.507 \AA$. Tentatively, we suggest that "proto-celadonite", may be the phyllosilicate in this sample as well. For the other sample $(417 \mathrm{~A}-46-2,28-32 \mathrm{~cm})$ analcite is much less of a contaminant (see Figure 3 ) and it would not be expected, therefore, to significantly affect either the bulk chemistry of the mineral separate or the 060 reflection. Inspection of the 060 reflections for this sample (see Figure 4) indicate clearly that trioctahedral saponite is dominant. Compared with Sample 417A-28-2, 106-110 cm, this cavity filling is more saponite-rich, a conclusion consistent with the higher $\mathrm{MgO}$ content of Sample 417A-46-2, 28-32 cm and the lower $\mathrm{Fe}_{2} \mathrm{O}_{3} / \mathrm{MgO}$ ratio. Again, there is an absence of a $10 \AA$ reflection (Figure 3), but the high $\mathrm{K}_{2} \mathrm{O}$ and $\mathrm{Al}_{2} \mathrm{O}_{3}$ contents of the sample (Table 1 ) and the 060 reflections at $1.507 \AA$ suggest the presence of a dioctahedral mineral, "proto-celadonite."

Evaluation of the X-ray diffraction data and chemical data for the mineral separates from Hole $417 \mathrm{D}$ is more straightforward and provides an interesting comparison with those from Hole 417A. Generally, fracture fillings from Hole 417D are dominated by reflections of smectite and a $9.8 \AA$ mineral, celadonite (see Figure 3 ), with smectite abundance apparently increasing as celadonite abundance decreases downhole. With the exception of a plagioclase reflection near $3.17 \AA$ for Sample 417D-23-1, 0-4 cm (see Figure 3), there is little evidence of contamination of these phyllosilicates.

Sample 417D-22-1, 32-34 cm provides the best example of the chemistry and X-ray diffraction characteristics of the $9.8 \AA$ phyllosilicate, celadonite, although there is evidence that smectite and a possible smectite-celadonite mixed layer mineral are present (see Figure 3). The 060 reflections for this sample are dominated by the strong $1.507 \AA$ reflection of celadonite with no evidence of a $1.532 \AA$ saponite peak or a $1.496 \AA$ peak of a dioctahedral, aluminous smectite (e.g., montmorillonite). However, there is a suggestion of a weak reflection near $1.520 \AA$ (see Figure 4 ) which could correspond with the dioctahedral smectite, nontronite. Chemically, the sample is more $\mathrm{Al}_{2} \mathrm{O}_{3}$-rich, with less $\mathrm{Fe}_{2} \mathrm{O}_{3}$, $\mathrm{MgO}$, and $\mathrm{K}_{2} \mathrm{O}$ than pure celadonite recovered from the Peru-Chile Trench (Scheidegger and Stakes, 1977). Admixtures of the nontronite with celadonite would not be expected to increase the $\mathrm{Al}_{2} \mathrm{O}_{3}$ content of Sample 417D-22-1, 32-34 cm to such a high amount. Accordingly, we postulate that the celadonite found in this sample may be a highly aluminous celadonite with appreciable $\mathrm{Al}^{+3}$ substituting for $\mathrm{Fe}^{+3}$ in the octahedral layer. For samples from Hole 417D, the size of the 001 celadonite peak (Figure 3) is directly proportional to the $\mathrm{K}_{2} \mathrm{O}$ content of the sample (see Table 1).

$\mathrm{X}$-ray diffraction and chemical study of Samples 417D$23-1,0-4 \mathrm{~cm}$ and 417D-44-1, 96-100 $\mathrm{cm}$ indicates that the celadonite is least abundant in the latter sample (see Figure 3 ). This corresponds to a decrease in the relative magnitude of the $1.507 \AA 060$ reflection (see Figure 4 ) and a decrease in $\mathrm{K}_{2} \mathrm{O}$ and $\mathrm{Al}_{2} \mathrm{O}_{3}$ contents (see Table 1). The 
chemical data also indicate that both $\mathrm{MgO}$ and $\mathrm{Fe}_{2} \mathrm{O}_{3}$ * (total) increase with depth in the section. It is possible that a part of the increase in total iron might be associated with nontronite, since the 060 reflections for the samples from $417 \mathrm{D}$ suggest that there is a peak near $1.518 \AA$. Equally likely, however is the possibility that a significant portion of the increase in total iron with increasing depth in the section may be related to an iron-rich saponite. Although the small volumes of samples used in this study precluded evaluation of the $\mathrm{Fe}^{+3} / \mathrm{Fe}^{+2}$ ratio, we suspect that this ratio would have been quite low for Sample 417D-44-1, 96-100 cm, which would imply that considerable ferrous iron was in the octahedral layer of saponite.

In summary, mineral separates from cavities and veins of altered rocks from 417A and 417D indicate that significant differences in the chemistry and mineralogy of secondary minerals exist between holes. For Hole 417A, the secondary minerals are notably $\mathrm{Al}_{2} \mathrm{O}_{3}$-rich with analcite and aluminous-smectite (montmorillonite) present, and somewhat $\mathrm{Fe}_{2} \mathrm{O}_{3}$-poor, with the trioctahedral smectite, saponite, not being as iron enriched as those from Hole 417D. For Hole 417D, crystalline celadonite and iron-rich saponite are dominant and there is a suggestion that nontronite may be present. Generally, the vein and cavity fillings from Hole 417D have more $\mathrm{Fe}, \mathrm{Mg}$, and $\mathrm{K}$ and less $\mathrm{Si}$ and $\mathrm{Al}$ than do those from Hole 417A.

\section{BULK MINERALOGY OF ALTERED ROCKS}

Mineral data discussed in this section were obtained from the analysis of the $<2 \mu \mathrm{m}$ fraction separated from ground pieces of altered rock. As discussed previously, the altered rock samples are believed to be representative of the diversity of alteration found in Holes 417A and 417D. Using as guides the X-ray diffraction data obtained on mineral separates from different depths in the crustal sections, it is possible to evaluate more rigorously the bulk mineral data. The locations of samples discussed in this section are shown in Figure 2. Diffractograms obtained from glycerol-solvated and glycolated, oriented mounts of this material are illustrated in Figure 5. In Figure 6, we present data on the 060 reflections obtained from random mounts of similar, but untreated, samples.

Considering first the reflections near $28^{\circ} 2 \theta$, which we attribute to feldspar, a very fundamental distinction in the character of the feldspar between samples from Holes 417A and 417D is apparent. Hole 417D samples have reasonably sharp peaks between 3.17 and $3.19 \AA$ and associated weaker reflections between 21 and $27^{\circ} 2 \theta$, indicating the expected occurrence of plagioclase, a primary mineral of unaltered basaltic rocks. By comparison, Hole 417A samples have feldspar reflections between 3.22 and $3.25 \AA\left(\sim 27.4^{\circ} 2 \theta\right)$ and weaker ones between 21 and $27^{\circ} 2 \theta$ (see Figure 5). Data summarized by Borg and Smith (1969) indicate that plagioclase feldspars have strong reflections between 3.18 and $3.21 \AA$, whereas, potassium feldspars have their strongest reflections between 3.24 and $3.31 \AA$. In addition, the strongest of the weaker reflections near $24^{\circ}$ gives a spacing of about $3.78 \AA$ for Hole $417 \mathrm{~A}$ samples, but only about $3.74 \AA$ for Hole $417 \mathrm{D}$ samples. This shift in peak position and the difference in position of the principal feldspar peak near $28^{\circ} 2 \theta$ is consistent with that expected for potassium

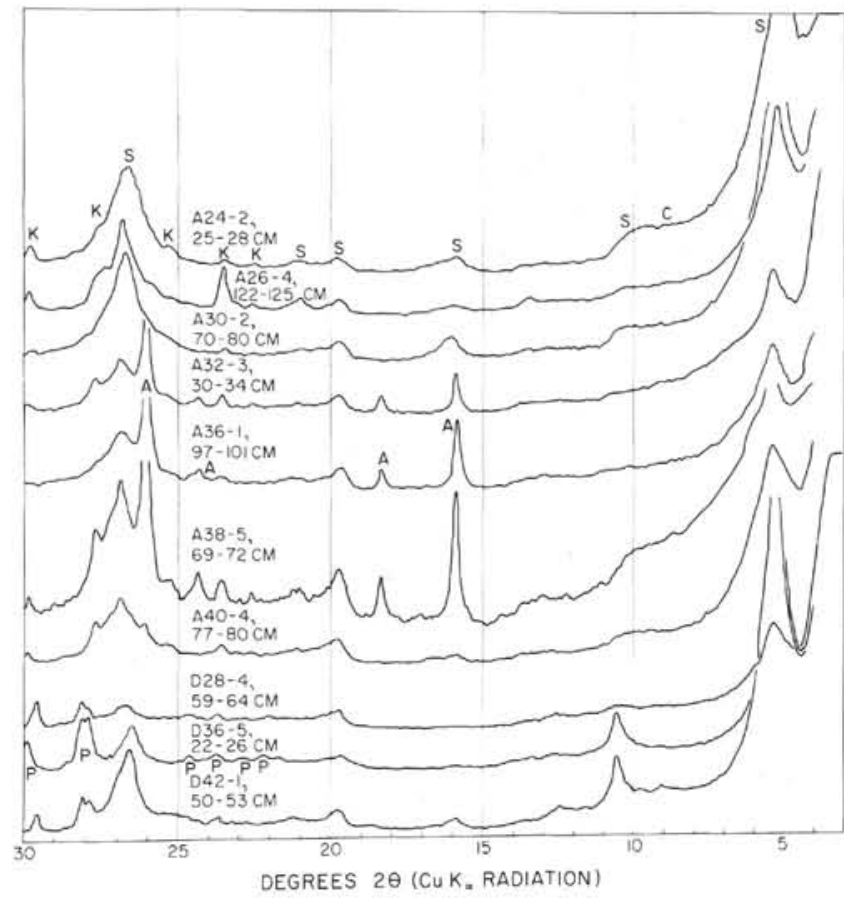

Figure 5. X-ray diffraction patterns of minerals found in large pieces of altered basalt recovered from Holes $417 \mathrm{~A}$ and $417 D$. All diffractograms were obtained from oriented, glycolated mounts of the $<2$ micron fraction of bulk samples ground in distilled water. $S=$ smectite, $C=$ celadonite, $A=$ analcite, $P=$ plagioclase, and $K=$ potas sium feldspar.

feldspar (maximum microcline), being the dominant feldspar in altered Hole $417 \mathrm{~A}$ rocks and intermediate plagioclase feldspar in the less-altered 417D rocks.

Another principle difference between alteration products found in the two sites concerns the occurrence of analcite. The diffractograms from oriented slides (Figure 5) show the common presence of the sodium zeolite in samples from $417 \mathrm{~A}$, but not in samples from 417D.

The 001 and higher order reflections of smectite dominate most diffractograms (see Figure 5) and indicate that expandable clay minerals are the characteristic type of phyllosilicate present in altered rocks from both sites. Evidence for a $10 \AA$ reflection on the diffractograms is weak, although there is a suggestion of such a peak for Samples 417A-24-2, $25-28 \mathrm{~cm}$; 417A-30-2, 40-48 cm; 417A-38-5, 69-72 cm; and $417 \mathrm{D}-42-1,50-53 \mathrm{~cm}$. These samples have strongest reflections between 3.31 and $3.33 \AA$ (near $26.5^{\circ} 2 \theta$; Figure 5). Comparable diffractograms of glycerol-solvated samples from the Peru-Chile Trench (see Scheidegger and Stakes, 1977) show similar peaks, but the 005 reflections are generally much weaker. We postulated that the enhanced reflection occurring near $26.5^{\circ} 2 \theta$ coincides with the 005 reflections of smectite and the 003 reflections of celadonite. Work by Seyfried et al. (1976) suggests that iron-rich, glycolated celadonite has a stronger 003 reflection than 001 reflection, and that even numbered, higher-order reflections are very weak. From data presented in Figure 5, it is apparent that smectite and perhaps celadonite are present in altered rocks from Holes 417A and 417D. 


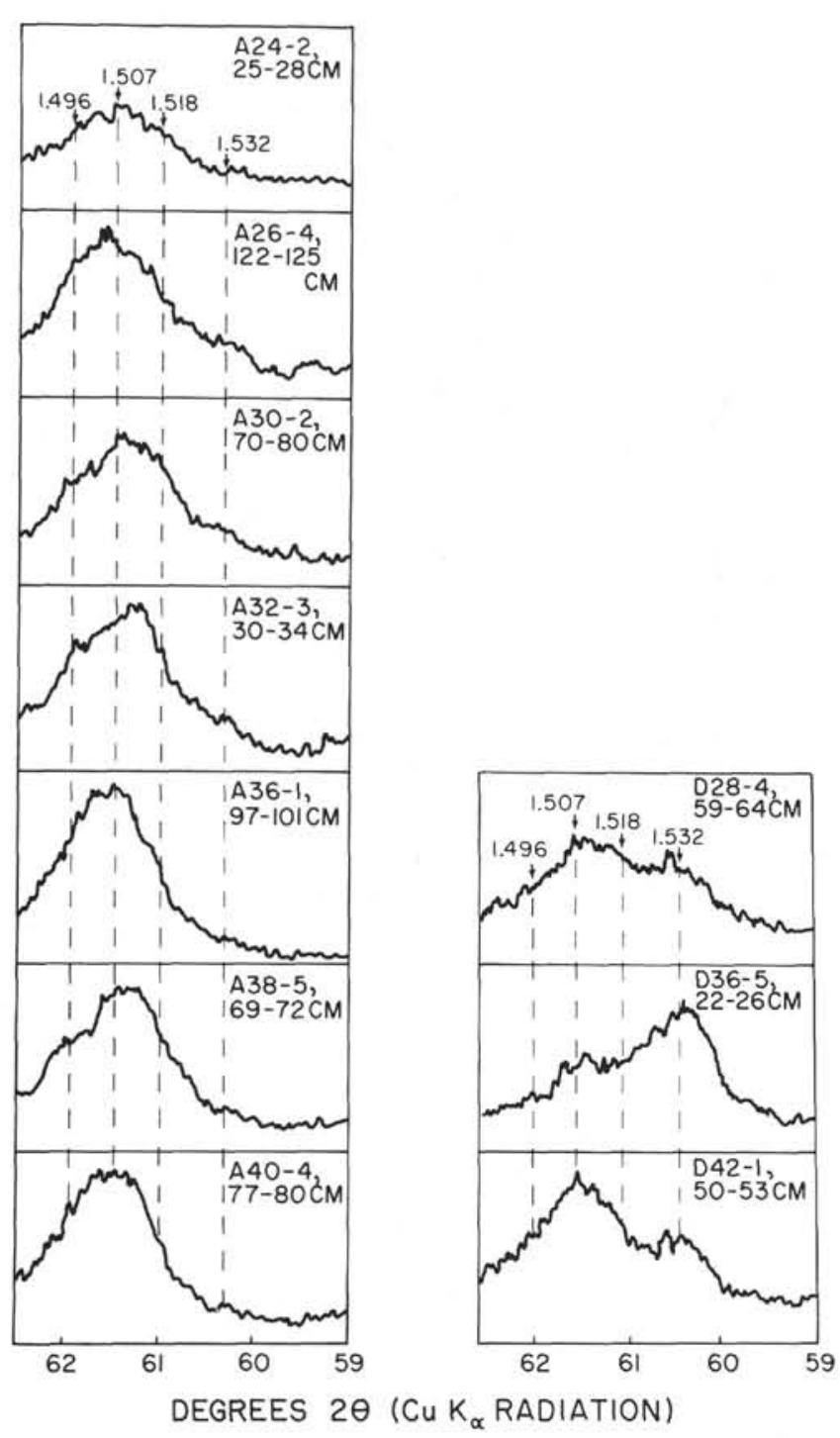

Figure 6. X-ray diffraction patterns used to study the 060 reflections of samples selected for bulk mineral study. Again, numbers above arrows correspond to spacings in $\AA$. Note the presence of 1.496 and $1.507 \AA$ peaks for samples from Hole $417 A$ and the 1.507 and $1.532 \AA$ peaks for samples from Hole 417D. As discussed in text, such spacings are believed to be associated with montmorillonite (and/or analcite) and celadonite in Hole $417 \mathrm{~A}$ rocks, and celadonite and iron-rich saponite in Hole $417 D$ rocks.

Additional information on the character of the phyllosilicates present in Hole 417A and 417D samples is obtained from study of the 060 reflections of these samples (see Figure 6). For Hole 417A, a strong broad reflection occurs, centered between $1.507 \AA$ and $1.510 \AA$, that is believed to coincide with celadonite (see previous discussion; Seyfried et al., 1976). Surprisingly, although diffractograms of oriented slides of this material indicate ubiquitous smectite, the 060 reflections indicate surprisingly little trioctahedral smectite (e.g., saponite). Instead, it appears that the smectites are largely dioctahedral. Unfortunately, the " 060 " reflection of analcite at $1.496 \AA$ for Samples $417 \mathrm{~A}-32-3,30$ -
$34 \mathrm{~cm}$; 417A-36-1, 97-101 cm; and 417A-38-5, 69-72 cm complicates the interpretation. Nevertheless, other samples from Hole 417A indicate the presence of a possible smectite 060 reflection near $1.496 \AA$ (montmorillonite), a result consistent with the interpretation of 060 reflection for the mineral separates (see Figure 4).

The 060 reflections for the Hole 417D samples again provide interesting comparison with the Hole 417A samples. For the three samples from Hole 417D, we observe a strong 060 reflection near $1.532 \AA$ (see Figure 6), indicating the presence of an iron-rich saponite similar to those found in minerals separated from other Hole 417D samples (see Figure 4). In addition, there is little suggestion of a possible $1.496 \AA$ reflection, which would indicate the presence of montmorillonite. The reflection near $1.507 \AA$ is believed to be associated with celadonite. Again, it is interesting to note that for Sample 417D-36-5, 22-26 cm, a relatively weak 005 reflection of saponite (see Figure 5) is also associated with a weak $1.507 \AA$ celadonite reflection, implying that a strong 060 reflection near $1.507 \AA$ and an unusually strong $3.32 \AA$ peak may be useful in indicating the presence of "protoceladonite." However, if the smectite is montmorillonite, work by MacEwan (1961) would indicate that an enhanced 005 reflection, relative to other higher order basal reflections, would be expected for oriented, glycolated samples.

Summarizing the bulk mineral study of Hole 417A and 417D altered rocks, we find that several differences exist both in regard to phyllosilicates and other secondary minerals. For Hole $417 \mathrm{~A}$, analcite and potassium feldspar are common; for Hole 417D, plagioclase is the feldspar and zeolites (e.g., analcite) are not evident. For smectite, a characteristic secondary alteration product found in all samples, it appears likely that significant differences in mineral species exist between the two sites. For Hole 417A, enhanced 005 basal reflections of glycolated smectite and 060 reflections near $1.496 \AA$ suggest that the principle smectite is the aluminous, dioctahedral smectite, montmorillonite; this result is consistent with the chemical composition of zeolite-free and feldspar-free mineral separates (compared in Table 1 and Figure 3). For the Hole 417D smectites, we find that the 060 reflections at $1.532 \AA$ are much more dominant, the 005 basal reflections are generally weaker, and the $1.492 \AA 060$ reflection is absent. Accordingly, we suggest that iron-rich saponite, perhaps, admixed with some dioctahedral nontronite, is the dominant smectite in Hole 417D altered rocks. Additionally, weak or absent $10 \AA$ reflections with prominent 060 reflections near $1.507 \AA$ suggest that "proto-celadonite" may be common in altered rocks recovered from both sites.

\section{DISCUSSION OF RESULTS}

\section{Secondary Mineral Assemblages of Holes 417A and 417D}

Secondary minerals associated with altered rocks from Hole 417D are principally iron-rich saponite, celadonite, calcite, and possibly nontronite, and are similar to minerals that have been reported from other altered oceanic crustal rocks (e.g., Seyfried et al., 1976; Bass, 1976; Scheidegger and Stakes, 1977; Barager et al., 1977). The presence of pyrite in Hole 417D rocks (Robinson, 1977), and the presence of calcite suggest that the conditions were gener- 
ally nonoxidizing and alkaline. In many respects, the secondary mineral assemblages of Hole 417D correspond with the nonoxidative diagenetic mineral assemblage described by Bass (1976) for rocks collected from the Nazca plate during DSDP Leg 34. Oxygen isotope studies on minerals produced under nonoxidative conditions in other altered oceanic crust indicate that low temperatures prevailed $\left(\sim 4^{\circ} \mathrm{C}\right.$; Muehlenbachs and Scarfe, 1977). Accordingly, it is apparent that under low-temperature, alkaline, nonoxidizing conditions, iron and magnesium in ferromagnesian minerals and in associated mesostasis are mobilized, leading to the common precipitation of iron and magnesium-rich smectites in available pore spaces in altered rocks (Scheidegger and Stakes, 1977). Plagioclase feldspar is not notably altered under such conditions (Bass, 1976).

The secondary mineral assemblage associated with the more highly altered Hole 417A crustal rocks shows much more diversity, with potassium feldspar, analcite, montmorillonite, proto-celadonite, saponite, and calcite being present. When compared with the Hole 417D assemblage, we find that potassium feldspar, analcite, and montmorillonite are the notable additional secondary mineral phases, and saponite is uncommon. All of these additional mineral species are highly aluminous and, with the exception of montmorillonite, show enrichments of the alkali metals.

The greater diversity of alteration products found in Hole 417A, when compared with Hole 417D rocks, obviously coincides with differences in the conditions of alteration or in the length of time the rocks were subjected to progressive alteration. One of the obvious differences between the nature of alteration that affected the two sites concerns the greater degree of oxidation of Hole 417A rocks (Donnelly, 1977). Circulation of considerably oxygenated sea water, perhaps enhanced by the somewhat elevated topographic position of Site 417 relative to Site 418, could have brought about the extensive oxidation that crustal rocks at Hole 417A experienced (Donnelly, 1977). Some of the mineral characteristics associated with the more oxidized Hole 417A rocks (e.g., the presence of poorly crystalline celadonite; absence of iron-rich saponite) can be attributed to such extensive oxidation, a condition favoring the formation of celadonite and the destruction of smectites (Bass, 1976). From the mineral data presented above (see Figures 4 and 6), it is apparent that although celadonite is very common, saponite is not present or very uncommon in Hole 417A. Only for the sample recovered from the lowest level in the studied portion of the crustal section $(417 \mathrm{~A}-40-44,77-80 \mathrm{~cm})$ is the 060 saponite reflection definitely larger than the celadonite reflection (see Figures 4 and 6).

The highly aluminous character of many of the secondary minerals found in Hole 417A rocks can be explained most easily by the alteration of primary plagioclase feldspar in these rocks, but not in those from Hole 417D. By remobilizing aluminum, sodium, and calcium during plagioclase alteration, elements required for the formation of aluminous smectite (montmorillonite), analcite, and calcite would be available. Conditions favoring the alteration of plagioclase remain problematical since plagioclase is typically little affected by low temperature alteration (e.g., Bass, 1976; Scheidegger and Stakes, 1977). Calling on elevated temperatures to bring about plagioclase alteration in Hole 417A is not in accord with the presumed low-temperature alteration conditions envisioned for this site (Donnelly, 1977). Accordingly, we suggest that plagioclase alteration in Hole $417 \mathrm{~A}$ rocks occurred under low temperature, highly oxidizing conditions, perhaps enhanced by anomalously high $p \mathrm{H}$.

The presence of well-crystalline celadonite in Hole 417D samples (see Figure 3 ) and the presence of poorly crystalline "celadonite" in Hole 417A rocks may also reflect fundamental differences in the nature of the alteration process that affected both crustal sections. For the upper part of the Hole 417D crustal section, circulating fluids (presumably sea water) were able to bring about sufficient oxidation of iron to enable celadonite to develop. Similarly, potassium concentration in the circulating fluids must have been sufficiently high to bring about the development of the ordered, layered structure of a micaceous mineral. We speculate that the iron-rich saponite intimately associated with the celadonite in the Hole 417D rocks may have been a precursor of the celadonite, since oxidation and potassium addition could easily transform a smectite into a celadonite. The continued presence of much iron-rich saponite in the Hole 417D samples argues for limited oxidation.

For the Hole 417A crustal section, conditions were much different and crystalline celadonite was not formed. The extensive oxidation noted above for the Hole 417A rocks lead to the destruction of all iron-rich saponites, but may have favored the formation of aluminous smectite, montmorillonite. The 060 reflections indicate clearly that the dioctahedral structure of celadonite was formed during the oxidation, perhaps of iron-rich saponite precursors (see Figure 6). However, unlike Hole 417D, development of the threedimensional ordered structure of celadonite must have been inhibited by the lack of potassium. The potassium feldspar found in these samples is an additional sink for $\mathrm{K}$ and may have been favored by the strongly oxidizing conditions. The celadonite in Hole 417A altered rocks is envisioned to be largely a smectite-celadonite-mixed layer mineral, whose basal reflections are dominated by the expandable smectite, montmorillonite (see Figures 3 and 5).

\section{Evidence for Evolutionary Changes in the Composition of Secondary Minerals}

A principle objective of this report is to compare the chemical composition of secondary minerals found in fracture and vesicle fillings from DSDP Holes 417A and 417D with comparable, but younger, materials found in altered oceanic crust recovered from other parts of the world's oceans. The basic assumption implicit in such an analysis is that fracture and vesicle fillings can provide information on the chemistry of fluids that have permeated through the rocks (Scheidegger and Stakes, 1977). Accordingly, if the compositions of fluids that circulate through aging crust are time-dependent, the chemistry of minerals found in the rocks might be sensitive indicators of progressive changes in solution chemistry. With few exceptions, most studies of secondary minerals found in vesicles and fractures have used an electron microprobe, and detailed mineral work on the probed material has not always been forthcoming. As a result, in our analysis we have had to rely on bulk chemical analyses alone, and not on relative abundances of particular mineral species. 
Available data on the chemical composition of such secondary products were obtained from Baragar et al.(1977), Banks (1972), Melson and Thompson (1973), Bass (1976), Seyfried et al. (1976), Scott and Swanson (1976), Scheidegger and Stakes (1977), and the present study. The analyzed samples in these papers are believed to be representative of the compositions of alteration products found in oceanic crust, both in regard to age ( 0 to 110 m.y.B.P.) and location (Nazca plate in the southeast Pacific; St. Paul's Rocks; dredges and DSDP Leg 37 cores from the North Atlantic). Since our initial inspection of the chemical data revealed that the relative proportions of $\mathrm{Fe}, \mathrm{Mg}, \mathrm{Al}$, and $\mathrm{K}$ were most variable, the data from each report were plotted on $\mathrm{Al}_{2} \mathrm{O}_{3}-\mathrm{MgO}-\mathrm{Fe}_{2} \mathrm{O}_{3} *$ and $\mathrm{Fe}_{2} \mathrm{O}_{3} *-\mathrm{MgO}-\mathrm{K}_{2} \mathrm{O}$ ternary diagrams (see Figure 7).

Inspection of the data summarized in Figure 7 reveals the interesting, rather uniform composition of alteration products recovered from particular areas and the inhomogeneity that exists among areas. In addition, when all populations are considered together, they define distinctive trends. One involves an increase in the $\mathrm{Fe}_{2} \mathrm{O}_{3} * / \mathrm{MgO}$ ratio at relatively constant $\mathrm{K}_{2} \mathrm{O}$, which in turn is followed by an increase in $\mathrm{K}_{2} \mathrm{O}$. The other trend corresponds to an increase in the $\mathrm{Fe}_{2} \mathrm{O}_{3} * / \mathrm{MgO}$ ratio at relatively constant $\mathrm{Al}_{2} \mathrm{O}_{3}$, which in turn is followed by an increase in $\mathrm{Al}_{2} \mathrm{O}_{3}$. We find these rather dramatic differences in chemistry of secondary min- erals to be very intriguing, because the authors who described the products suggested that the secondary minerals formed in basalts of rather uniform initial composition from low-temperature sea water alteration.

Compositional variations within groups are both distinctive and restrictive, and are believed to reflect the limited compositional variability of secondary fluids responsible for their formation. Much of the scatter in composition (e.g., changes in $\mathrm{Fe}_{2} \mathrm{O}_{3} * / \mathrm{MgO}$ ratio; Figure 7) could be caused by differences in the relative amounts of secondary minerals (e.g., saponite and nontronite; see Scheidegger and Stakes, 1977).

Causes for the differences in composition among populations of samples and for the trends noted on the ternary diagrams can be perhaps better understood by considering the age relationships among the samples. Samples from DSDP Leg 37 are believed to be the youngest (3.67 to 14.45 m.y.B.P.; Mitchell and Aumento, 1977), samples from the Nazca plate are of intermediate age (15 to 50 m.y.B.P.; Hogan and Dymond, 1976; and Scheidegger and Stakes, 1977), and those from DSDP Leg 51 are oldest at about 108 m.y.B.P. No age was given for the samples from $22^{\circ} \mathrm{N}$ on the Mid-Atlantic Ridge (Banks, 1972), although they would be assumed to be quite young. Similarly, the ages of samples from St. Paul's Rocks are not well established; $\mathrm{Rb}-\mathrm{Sr}$ measurements indicate that peridotites on St. Paul's

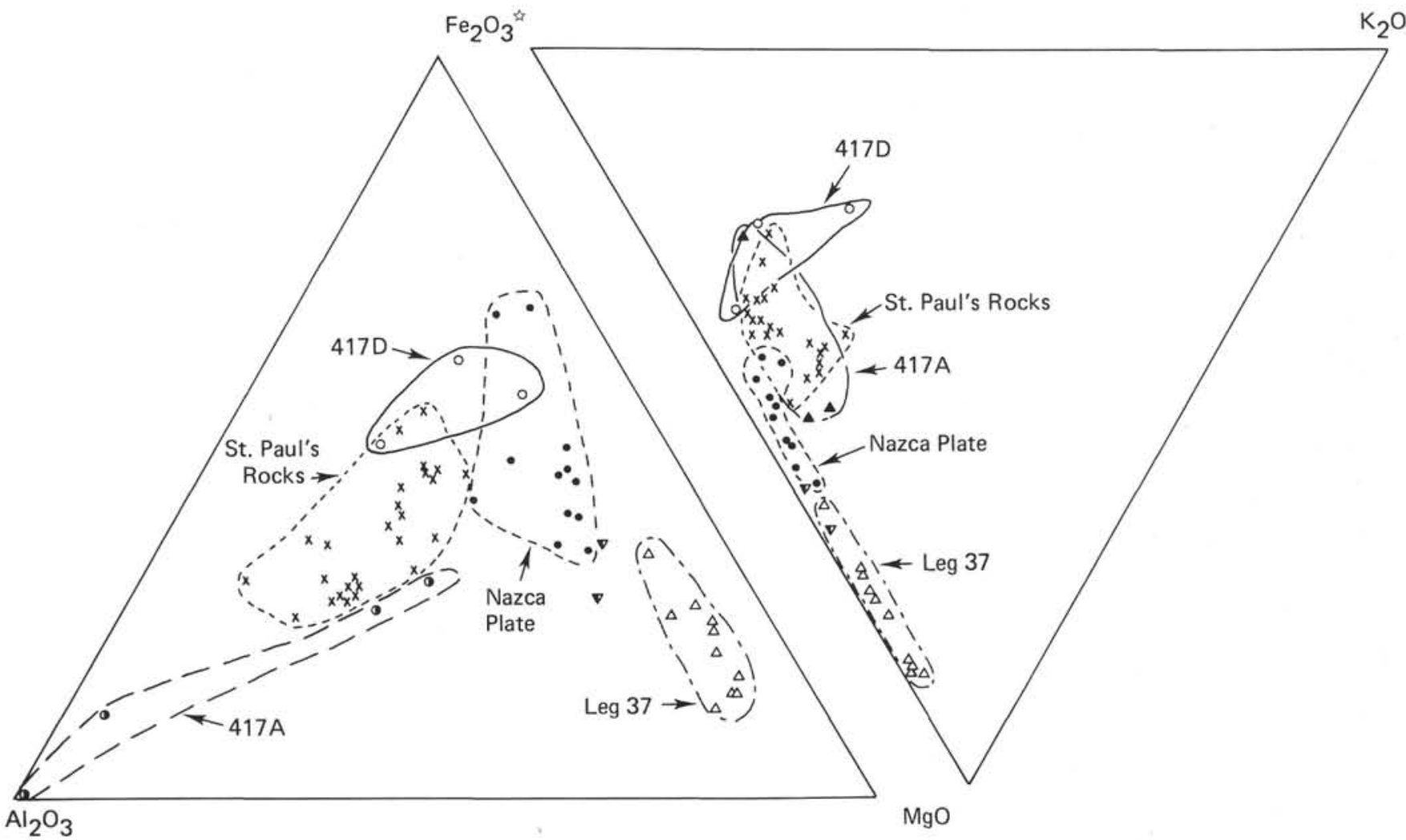

Figure 7. $\mathrm{Al}_{2} \mathrm{O}_{3}-\mathrm{Fe}_{2} \mathrm{O}_{3}{ }_{-} \mathrm{MgO}$ and $\mathrm{MgO}-\mathrm{Fe}_{2} \mathrm{O}_{3} *_{-} \mathrm{K}_{2} \mathrm{O}$ ternary diagrams showing the relationship of the chemistry of secondary minerals found in fracture fillings from Holes $417 \mathrm{~A}$ and $417 \mathrm{D}$, with similar products found in younger oceanic crust. See text for listing of papers in which analyses are presented. Note that the two most aluminous samples from Hole 417 A contained significant quantities of analcite. Samples noted by inverted triangles ( $\nabla$ ) represent analyses from Banks (1972) on rocks dredged from the Mid-Atlantic Ridge at $22^{\circ} \mathrm{N}$. 
Rocks may have been emplaced less than 100 m.y. ago (Melson et al., 1972); whereas, associated pillow basalts may be considerably younger ( $<20 \mathrm{~m} . \mathrm{y}$.; Melson and Thompson, 1973). Since the alteration products found in veins, fractures, and vesicles of pillow basalts from St. Paul's Rocks are much like those associated with the Site 417 material (i.e., they are $\mathrm{Al}_{2} \mathrm{O}_{3}$ and $\mathrm{K}_{2} \mathrm{O}$-rich), it is tempting to suggest that these minerals may have been derived from solutions coming from the alteration of underlying ultramafic rock masses. The elevated nature of St. Paul's Rocks may have favored the same type of alteration that is characteristic of Hole 417A.

On the basis of the noted age relationships, we see that minerals found in young oceanic crust $(<15$ m.y.B.P.) are notably $\mathrm{MgO}$-rich. Mineralogically, saponite would be expected to be the dominant secondary mineral phase. Alteration products in crust of intermediate age ( 15 to 50 m.y.B.P.) are notably more $\mathrm{Fe}_{2} \mathrm{O}_{3}$ *-rich, although they have relatively low $\mathrm{K}_{2} \mathrm{O}$ contents similar to that of alteration products associated with younger crust (see Figure 7). For the secondary products associated with old oceanic crust, we find that they are typically enriched in $\mathrm{Al}_{2} \mathrm{O}_{3}$ and $\mathrm{K}_{2} \mathrm{O}$. The Hole 417D secondary minerals have relatively less $\mathrm{Al}_{2} \mathrm{O}_{3}$ than Hole $417 \mathrm{~A}$ minerals, and are compositionally more similar to those associated with younger rocks from the Nazca plate, suggesting that duration or extent of exposure to sea water is more important than the age of the crust. Secondary minerals found in pillow basalts from St. Paul's Rocks are similar to the $\mathrm{Al}_{2} \mathrm{O}_{3}$-rich, non-zeolite-bearing secondary minerals formed under intense oxidizing conditions from Hole 417A. Interestingly, the clay minerals from St. Paul's Rocks are dark to light yellowish orange (Melson and Thompson, 1973), an observation consistent with clay minerals significantly influenced by oxidation (Bass, 1973).

Speculatively, we envision that the compositional trends defined by the different secondary mineral sample populations of different ages (see Figure 7) can be interpreted in terms of the temporally varying composition of fluids which have circulated through the rocks. Earliest formed solutions, which resulted in the formation of saponite dominated secondary mineral assemblages, were highly magnesium-rich, an observation with experimental studies and conditions expected for non-oxidative diagenesis (Bass, 1973). Under high water:rock ratios, magnesiummagnesium-rich smectites would be expected to precipitate from hydrothermal systems (Seyfried and Mottl, 1977). Many of the alteration products associated with crust of intermediate age are also consistent with minerals believed to have formed under largely nonoxidative conditions, perhaps during the waning stages of hydrothermal alteration. Unlike their younger counterparts, they are more ironrich and typically have iron-rich saponites and nontronites intimately intermixed. For the oldest rocks, secondary minerals become typically $\mathrm{Al}_{2} \mathrm{O}_{3}$-enriched. As noted previously during the discussion of alteration products found associated with Hole $417 \mathrm{~A}$ altered crust, we believed that such changes correspond to the effects of severe oxidative diagenesis, a process which would be expected to bring about the destruction of smectite precursors associated with hydrothermal precipitates, the alteration of primary plagioclase feldspar, and the formation of celadonite-like clay minerals. Expected compositional changes accompanying such oxidative diagenesis would be the formation of more aluminous secondary minerals (e.g., potassium feldspar, montmorillonite, and zeolites) and micaceous-like, layered phyllosilicates. The micaceous minerals and potassium feldspar would provide an important sink for available potassium in solution, and the bulk alteration products found in veins, vesicles, and fractures would be expected to become more aluminous as this type of alteration proceeded (see Figure 7). We believe that such alteration may occur only in special topographic or tectonic settings (e.g., associated with topographic highs).

Temperatures of formation for smectites from DSDP Site 319 (Nazca plate), Sites 332 and 334 (Leg 37), and from Holes $417 \mathrm{~A}$ and $417 \mathrm{D}$ are believed to be very low $\left(<4^{\circ} \mathrm{C}\right)$ as indicated by oxygen isotopic compositions (e.g., Seyfried et al., 1976; Muehlenbachs and Scarfe, 1977). Thus, the secondary minerals were presumed to be products of a lowtemperature weathering phenomenon and not related to hydrothermally induced circulation as discussed in this report. Pure trioctahedral ferro-saponite from very young rocks from near the East Pacific Rise has been shown to have formed at substantially higher temperatures $\left(\mathrm{T}=150^{\circ}\right)$; whereas smectite (saponite and nontronite) and celadonite vesicle fillings from 30 to 50 m.y.B.P. crustal rocks recovered from the Peru-Chile Trench (Scheidegger and Stakes, 1977) formed at much lower temperatures $\left(\sim 40^{\circ} \mathrm{C}\right.$; Stakes and O'Neil, in preparation). Thus, any subsequent oxidation or recrystallization of a primary saponite by lower temperature hydrothermal fluids would result in a lowtemperature overprint masking higher temperature precursors. Addition of other phases at lower temperatures, which would be expected in the older samples, would produce similar results. Accordingly, the apparent low temperatures of formation noted in previous studies do not rule out a hydrothermal source of the constituents of the vein minerals. Even low-temperature gradients could drive a slow circulation to maximize alteration, explaining such localized areas of extensive alteration as seen in Hole 417A. High water:rock ratios and excess $\mathrm{Mg}$ would enhance saponite formation from constituents derived from initial hydrothermal leaching of deeper rocks or flow interiors. Subsequent compositional changes in the nature of the hydrothermal fluids could bring corresponding changes in the nature of secondary minerals. We speculate that changes in the $p \mathrm{H}$ and Eh of the pore water may be of far greater importance in determining the character of secondary minerals than the apparent temperature of formation.

In summary, we believe that the alteration that affected rocks collected from Hole 417D was dominantly nonoxidative in character and was operative when the Hole 417D crust was much younger. In contrast, the alteration that affected Hole 417A was much more pervasive and highly oxidizing. Smectites and other secondary minerals may have formed earlier in rocks from Hole 417A, only to be remobilized as conditions of alteration became more oxidizing. The pervasive alteration found in Hole 417A has led to a decrease in sonic velocities at all levels of Hole 417A, as compared with those from Hole 417D (this volume). Accordingly, observations of low sonic velocities in other old oceanic crust (Hart, 1973) may be associated with portions of the sea floor that experienced substantial oxidative diagenesis of initially hydrothermally altered, oceanic crust. 


\section{ACKNOWLEDGMENTS}

We wish to thank Mark Hower for performing the chemical analyses and assisting with the X-ray diffraction studies. We also wish to thank Roger Hart for many helpful discussions.

\section{REFERENCES}

Andrews, A.J., 1977. Low temperature fluid alteration of oceanic layer 2 basalts, DSDP Leg 37, Canadian J. Earth Sci., v. 14, p. 911-926.

Banks, H.H., Jr., 1972. Iron-rich saponite: additional data on samples dredged from the Mid-Atlantic Ridge, $22^{\circ} \mathrm{N}$ latitude, Smithsonian Contrib. Earth Sci. no. 9, p. 39-42.

Baragar, W.R.A., Plant, A.G., Pringle, G.J., and Schau, M., 1977. Petrology and alteration of selected units of Mid-Atlantic Ridge basalts sampled from Sites 332 and 335, DSDP, Canadian J. Earth Sci., v. 14, p. 837-874.

Bass, M.N., 1976. Secondary minerals in oceanic basalt, with special reference to Leg 34, Deep Sea Drilling Project. In Hart, S.R., Yeats, R.S., et al., Initial Reports of the Deep Sea Drilling Project, v. 34: Washington (U.S. Government Printing Office), p. 393.

Borg, I.Y., and Smith, D.K., 1969. Calculated x-ray powder patterns for silicate minerals, Geol. Soc. Am. Memoir 22, p. 896.

Deer, W.A., Howie, R.A., and Zussman, J., 1965. Rock forming minerals, 3. Sheet silicates: New York (Wiley).

Donnelly, T.W., 1977. The chemical budget of alteration at site 417A - a preliminary estimate, EOS Trans. Am. Geophys. Union, v. 58 , p. 1174.

Frey, F.A., Bryan, W.B., and Thompson, G., 1974. Atlantic Ocean floor: geochemistry and petrology of basalts from Legs 2 and 3 of the Deep-Sea Drilling Project, J. Geophys, Res., v. 79 , p. 5507.

Hart, R., 1970. Chemical exchange between seawater and deep ocean basalts, Earth Planet. Sci. Lett., v. 9, p. 269.

, 1976. Progressive alteration of the oceanic crust. In Hart, S.R., Yeats, R.S., et al., Initial Reports of the Deep Sea Drilling Project, v. 34: Washington (U.S. Government Printing Office), p. 433-437.

Hart, S.R., Nalwalk, A.J., 1970. K, Rb, Cs, and Sr; relationships in submarine basalts from the Puerto Rico Trench, Geochim. Cosmochim. Acta, v. 34 , p. 145.

Hogan, L. and Dymond, J., 1976. K-Ar and ${ }^{40} \mathrm{Ar}-{ }^{39} \mathrm{Ar}$ dating of Site 319 and 321 basalts. In Hart, S.R., Yeats, R.S., et al., Initial Reports of the Deep Sea Drilling Project, v. 34: Washington (U.S. Government Printing Office), p. 439.

MacEwan, D.M.C., 1961. The montmorillonite minerals (montmorillonoids). In Brown, G. (Ed.), The X-Ray identification and structure of clay minerals: London (Mineralogical Society of Great Britain), Chapter 4, p. 86.

Matthews, D.H., 1971. Altered basalts from Swallow Bank, an abyssal hill in the NE Atlantic, and from a nearby seamount, Phil. Trans. Roy. Soc. London, Ser. A, v. 268, p. 551.
Melson, W.G., Hart, S.R., and Thompson, G., 1972. St. Paul's Rocks, equatorial Atlantic: Petrogenic, radiometric ages, and implications on sea-floor spreading. In Shagam, R. (Ed.), Studies in Earth and Space Sciences (Hess volume): Geol. Soc. Am. Mem. 132, p. 241-272.

Melson, W.G. and Thompson, G., 1973. Glassy abyssal basalts, Atlantic sea floor near St. Paul's Rocks: petrography and composition of secondary clay minerals, Geol. Soc. Am. Bull., v. 84, p. 703.

Mitchell, W.S. and Aumento, F., 1977. Fission track chronology of basaltic glasses from DSDP Leg 37. In Aumento, F., Melson, W.G., et al., Initial Reports of the Deep Sea Drilling Project, v. 37: Washington (U.S. Government Printing Office), p. 625-628.

Muehlenbachs, K. and Scarfe, C.M., 1977. Low temperature alteration of basalts from DSDP Legs 52 and 53, site 418A, EOS Trans. Am. Geophys. Union, v. 58, p. 1174.

Robinson, P.T., 1977. Alteration of cretaceous basalts, DSDP sites 417 and 418, EOS Trans. Am. Geophys. Union, v. 58, p. 1174 .

Scarfe, C.M. and Smith, D.G.W., 1977. Secondary minerals in some basaltic rocks from DSDP Leg 37, Canadian J. Earth Sci., v. 14, p. 903-910.

Scheidegger, K.F. and Stakes, D.S., 1977. Mineralogy, chemistry and crystallization sequence of clay minerals in altered tholeiitic basalts from the Peru Trench, Earth Planet. Sci. Lett., v. 36 , p. 413-422.

Scott, R.B. and Hajash, A., Jr., 1976. Initial submarine alteration of basaltic pillow lavas: A microprobe study, Am. J. Sci., v. 276 , p. $480-501$.

Scott, R.B. and Swanson, S.B., 1976. Mineralogy and chemistry of hydrothermal veins and basaltic host rocks at hole $319 \mathrm{~A}$ and site 321. In Hart, S.R., Yeats, R.S., et al., Initial Reports of the Deep Sea Drilling Project, v. 34: Washington (U.S. Government Printing Office), p. 377-380.

Seyfried, W.E., Shanks, W.C., and Bischoff, J.L., 1976. Alteration and vein formation in Site 321 basalts. In Hart, S.R., Yeats, R.S., et al., Initial Reports of the Deep Sea Drilling Project, v. 34: Washington (U.S. Government Printing Office), p. 385 .

Seyfried, W.E. and Bischoff, J.L., 1977. Hydrothermal transport of heavy metals by seawater: The role of seawater/basalt ratio, Earth Planet. Sci. Lett., v. 34, p. 71-77.

Seyfried, W.E. and Mottl, M.J., 1977. Origin of submarine metal-rich hydrothermal solutions: Experimental basaltseawater interaction in a seawater-dominated system at $300^{\circ} \mathrm{C}$, 500 bars. In Paquet, H. and Tardy, Y., (Eds.), Proceedings of the Second International Symposium on Water-Rock Interaction, Strasbourg, France, p. 173-180.

Stakes, D.S. and O'Neil, J.R., in preparation. Mineralogy and stable isotope geochemistry of submarine hydrothermal systems.

Zvyagin, B.B., 1957. Determination of the structure of celadonite by electron diffraction: Soviet Phys. - Cryst., v. 2, p. 338-394. 